\title{
Indonesian Relations with the Eastern Europe, Soviet Union and China before 1965: Systemic and Domestic Factors
}

\author{
Mohd Noor Mat Yazid ${ }^{1}$ \\ ${ }^{1}$ Faculty of Humanities, Arts and Heritages, Universiti Malaysia Sabah, Kota Kinabalu, Malaysia \\ Correspondence: Mohd Noor Mat Yazid, Programme of International Relations, Faculty of Humanities, Arts and \\ Heritages, Universiti Malaysia Sabah, Kota Kinabalu, Sabah, 88400, Malaysia. Tel: 60-12-868-0362. E-mail: \\ mohdnoory2011@yahoo.co.uk
}

Received: March 13, 2016

Accepted: April 11, 2016

Online Published: July 19, 2016

doi:10.5539/res.v8n3p253

URL: http://dx.doi.org/10.5539/res.v8n3p253

\begin{abstract}
This article discusses the Indonesian relations with Eastern Europe Communist states, Soviet Union and China Communists before 1965 and how the systemic and domestic factors influenced Indonesian decision. Indonesian foreign relation was closer to communist state after President Sukarno's official visits to Moscow and Beijing in 1956. Why President Sukarno foreign relations closer to communist states? What was the international political situation that influenced Sukarno to lean to East bloc? What was the domestic situation that influenced Sukarno to do so? Why Indonesian closer relation with the communist not began earlier than 1956? Among the main discussions in this article are: the Indonesian-Soviet Union relations, Indonesian-China relations, Communist ideology and Indonesian relations with Eastern European Communists states. Indonesian relations with Communists state changed dramatically after the Indonesian Coup of September 1965 and the collapsed of President Sukarno and the formation of "new order" regime under Suharto in Indonesia. The changes of domestic politics in Indonesia after September 1965 strongly influenced the Indonesian relations with the Communists states.
\end{abstract}

Keywords: Indonesia, Soviet Union, China, new order, Suharto, Sukarno, Indonesian Coup, Eastern Europe

\section{Introduction}

This article discusses the Indonesian relations with Eastern Europe Communist states, Soviet Union and China Communists before 1965 and how the systemic and domestic factors influenced Indonesian decision towards the communist states. Indonesian foreign relations were closer to communist state since in the middle of 1950s, especially after President Sukarno's official visits to Moscow and Beijing in 1956. Why President Sukarno foreign relations closer to the communist states? What was the international political situation that influenced Sukarno to lean to East bloc? What was the domestic situation that influenced Sukarno to do so? Why Indonesian closer relations with the communist not began earlier than the mid-1950s? Among the main discussions in this article are: the Indonesian-Soviet Union relations, Indonesian-China relations, Communist ideology and Indonesian relations with Eastern Europe Communists states. The changes of domestic politics in Indonesia after Indonesian Coup of 30th September 1965 from "Old Order" under President Sukarno to "new order" under President Suharto played greater role in influencing the Indonesian relations with Communists state. Domestic political developments in Indonesia after September 1965 were not free from the systemic factors. The international political structure, especially the Cold War political configuration in the South East Asian region had close relations with the political domestic politics in Indonesia. The conflict and political struggle between "old order" and "new order" in Indonesian politics were closely related to the conflict and regional political struggle between The United States and Soviet Union in the South East Asian region.

Indonesia had close relations with the Soviet Union and China Communists since in the mid-1950s (Nadesan, 1979, pp. 20-27). After the Sino-Soviet split in 1963, Indonesia became closer to China than the Soviet Union. Indonesia-Soviet Union relations became chill after the "new order" regime took power in Indonesia in March 1966. The role played by the PKI (Partai Komunis Indonesia or Indonesian Communists Party) in Indonesian politics before September 1965 was important in the Indonesian decision towards the East bloc. Sukarno's dilemma in domestic politics gave an advantage to the communist ideology and it political movements under Chairman Aidit to strengthen the position of the communist ideology in Indonesian politics and Sukarno's 
government. The communist leadership under Chairman Aidit gave their support to almost all of the national policies under President Sukarno (e.g., in the West Irian Campaign 1962 and policy of confrontation with Federation of Malaysia 1963-1966). The PKI support to the Sukarno's national policies were important for the Indonesian Communists Party to attract Sukarno to be closer to them. On the Sukarno's side, he needed the PKI to balance the army's power and to encourage the rural population and poor peasant's support for the Sukarno government (Feith, 1964, pp. 969-980). After the banning of Masjumi (an Islamic Political Party) in 1960, Sukarno hoped the PKI would control the rural peasants to give their support to Sukarno's government. The role played by the PKI members in Sukarno's cabinet had influenced Sukarno's decision to lean towards the communist bloc, China and Soviet Union.

The Indonesian foreign policy and relations towards the communist countries changed when the PKI influence and its position in Indonesian politics was destroyed after the Indonesian Coup in 1965 (Nadesan, 1979, pp. 27-35). The new army leader, President Suharto, replaced President Sukarno. The Indonesian army under President Suharto (strongly backed by the United States) took power after 1965. The army was anti-communist and pro-West. The changes in the national ideology and political philosophy after 1965 gave a direct impact to the Indonesian foreign relations. The "new order" government under President Suharto changed the Indonesian foreign policy directionfrom pro-communists to anti-communists. After 1965 the foreign relations of Indonesia moved closer towards the Western countries. The changes in domestic politics are one of the important factors which determined the changes of Indonesian foreign policy after 1965. The domestic politics after 1965 gave a direct impact to the changes in Indonesian foreign policy. The Indonesian relations with capitalist Southeast Asian countries (Malaysia, Singapore, Thailand and the Philippines) improved dramatically after 1965. The confrontation policy towards Malaysia ceased in 1966 when the "new order" gaining power in Indonesian politics. The formation of pro-West and anti-communists regional Association (The Association of South East Asian Nations, ASEAN) on 8 August 1967 was closely related with the changes of domestic politics in Indonesia. Anti-communist Indonesian leaders such as Suharto and Adam Malik and Malaysian leaders, especially Tun Abdul Razak and Mohamad Ghazali Shafie played important roles in the early stage of the ASEAN formation. The political development in the Indonesian domestic level and regional anti-communists cooperation influenced the changes of Indonesian policy towards communist States after 1965.

\section{The Indonesia-Soviet Union Relations}

The political relations between Indonesia and Soviet Union were strongly determined by the philosophy and domestic politics of Indonesia. The harmonious and good relations during the period before 1965 influenced by the President Sukarno political philosophy and structure of domestic politics in Indonesia. The position of communists ideology especially the great leaders of Indonesian Communists Party such as Chairman Aidit, Nyoto and Lokman strongly influenced the Sukarno Indonesian policy towards Soviet Union. The harmonious relations ended after 1965 when communists' ideology and its political power collapsed in Indonesia.

Indonesia had close relations with the Soviet Union since mid-1950s. The close relations could be seen in state official visits between the two countries, financial aids, economic loans and investment from the Soviet Union to Indonesia (Hindley, 1963, pp. 107-119). Soviet Union also gave her support in military, technology and weapons support to Indonesian Sukarno. Soviet Union also gave her moral support to Indonesian struggles such as the West Irian Campaign 1962 and confrontation policy towards the Federation of Malaysia 1963-1966 (Derkach, 1965).

After the Sino-Soviet split in 1963 the relations between Indonesia-Soviet Union slightly changed, but Indonesia still received military and financial support from the Soviet Union (Derkach, 1965, pp. 566-571). Soviet Union still gave her support to Indonesia in the early stage of Indonesian new relations with Western bloc in mid 1960s (after the Indonesian Coup of 30th September, 1965). The support comprised of technological support, military training and equipment from Soviet to Indonesia continued until the "new order" administration under President Suharto formed their cabinet in 1966. On the day that President Sukarno's cabinet was dissolved, the Soviet Union called back all of her experts from Indonesia. It was in March 1966.

Indonesia still had close relations with the Soviet Union until the fall of President Sukarno, after the Indonesian coup of 1965. During the period of four months after the Indonesian Coup of 30th September 1965, the Soviet Union still had good relations with Indonesia. In February 1966, General Nasution assured the Soviet Defence Minister, Marshal Malinowski, that the Indonesian armed forces hoped for closer co-operation with the Soviet armed forces. The Indonesian armed forces were still being trained in Czechoslovakia and the Soviet Union and Indonesia was expecting the remainder of the Soviet Union's modern equipment for the air force under the executing purchase contract. Indonesia-Soviet relations were finally destroyed with the "new order" decision 
given to the Indonesian communists. The death sentence of Nyoto, a communist leader on February 1966 and the arrest of fifteen Indonesian ministers in March 1966 (cabinet ministers under President Sukarno), totally changed the Indonesia-Soviet Union relations. The Soviet Union called back her 60-70 Soviet technical experts to Indonesia. The chill in Soviet-Indonesia's relations began. The changes in Indonesian political leadership and her political philosophy under President Suharto influenced the cold relations with the Soviet Union.

\section{Indonesia-China Communists Relations}

Indonesian domestic politics and ideological factors played an important role in Indonesia-China Communists relations. During the period of before 1965, the position and communist ideology was strong in Sukarno Indonesian. The strong position of communists leader in Sukarno government influenced harmonious relations with China communists. Since Sukarno's state visit to China in 1956, the relations between the two countries improved constantly. The relationship was severed in the late 1965 when the domestic political ideology changed and "new order" under President Suharto gained power in Indonesian politics.

The PKI influence in Indonesian politics and Sukarno's domestic dilemma forced Indonesia to make closer relations with China communists during Sukarno's administration. It was started in 1956 when the PKI-PNI political coalition was formed. The PKI took a significant role in managing Indonesian politics after 1956. The PKI took over the roles played by the Masjumi before the broken political coalition in 1956. The banning of Masjumi and PSI (Partai Sosialis Indonesia or Indonesian Socialist Party) in 1960 made the PKI stronger position in Sukarno's government. Relations with China's communists improved with the role played by the PKI based upon the communist ideological and international communist co-operation.

Under Sukarno's regime, Indonesia was China's best hope in Asia as a potentially powerful and strategically located anti-Western force complementing Chinese policy (Berth, 1975, p. 473). China Communists invited President Sukarno to Beijing in 1956 and proceeded to consolidate further ties with Indonesia through aid, trade and technical assistance.

The Indonesia-China relations dramatically changed after the Indonesian Coup of 30th September 1965. There was little chance of good relations between China and General Suharto's regime from the beginning. The significant factor was the political ideology of Suharto. The allegation that China was actively involved and supported the PKI in the 1965 Indonesian Coup was one reason to explain to the Indonesian mass population in the early period after the 1965 event. Whether the coup was supported and the PKI responsible was not important in explaining the Indonesia-China relations after 1965. The coup was officially declared by President Suharto's regime that the PKI had led it and was responsible for the death of six military generals. The Indonesian mass population's perception in the years after GESTAPU (Gerakan Tiga Puluh September or The 30th September Movements) was that the communists were responsible for the 1965 Indonesian Coup. The key point was President Suharto's policy which was anti-communist and pro West. The PKI's and communist ideology must be destroyed for the "new order" policy's survival.

Suharto reoriented his foreign policy by repairing relations with the Western countries, renegotiated the massive debts left over from President Sukarno's period with Western countries, solicited aid from Japan and Western countries and opened the country up to foreign investment (Mahajani, 1967, pp. 214-234). Suharto's pro-West and anti-communist leaning influenced Indonesian foreign relations and regional co-operation in the Southeast Asian region. Indonesia's relations with China were frozen from 1966 until 1990. The frozen relationship was dominated by Suharto's anti-communist policy and the "new order" political survival. The rapprochement in 1990 was due to the changes of China's leadership and the new economic policy in China. The collapse of the Cold War at an international level also influenced Indonesia's decision. The changes in the international political structure and liberal economic policy in China led to the Indonesia-China rapprochement in the early 1990s.

\section{Indonesian Relations with Eastern Europe Communists States}

Indonesian relations with Eastern European countries (pro-Soviet Union communists state such as Poland, Romania, East Germany, Bulgaria and Czechoslovakia) were determined by the domestic political and ideological factors in Indonesia. The relationship was different during the period of before and after 1965 because of the changed domestic politics in Indonesia. Indonesia had good relations with Eastern Europe since the late 1950's until the fall of Sukarno after the September event in 1965. The ideological factor played an important role in the relations with communist countries in Eastern Europe. Indonesia had received financial aids, loans and investment from Eastern European countries since the mid-1950's. The East European aids and agreement with Indonesia can be seen in Table 1 below. 
Table 1. East European aid and agreement with Indonesia

\begin{tabular}{ll}
\hline Dates & Country/amount \\
\hline February 1955 & East German loan of USD 9.2 millions. \\
March 1955 & Romanian loan of approximately USD 2 millions \\
May 1956 & Czech loan of USD 1.6 millions. \\
1957 & Czech loan of USD 0.8 millions. \\
1958 & Czech loan of USD 6 millions. \\
1958 & Polish loan of USD 39.1 millions. \\
1959 & Polish loan of USD 5 millions. \\
September 1959 & Czech loan of USD 14 millions. \\
July 1960 & Czech loan of USD 33.8 millions. \\
1960 & East German loan - amount unknown. \\
May 1961 & Bulgarian loan of USD 5 millions. \\
August 1961 & Polish loan of USD 30.1 millions. \\
September 1961 & Hungarian loan of USD 29.6 millions. \\
November 1961 & Romanian offer of USD 50 millions. \\
\hline
\end{tabular}

Source: Hindley, D. (1963, Summer). Pacific Affairs, 36(2), 108-109.

Poland provided the biggest amount of loan to Indonesia during the period of 1959 to 1961 . The total loan was USD 74.1 million (USD 39.1 million in 1958, USD 5 million in 1959 and USD 30.1 million in August 1961). Czechoslovakia provided five loans for Indonesia from 1956 until 1960 with the total amount of USD 56.2 million. The first loan approved in May 1956 (USD 1.6 million), second loan in 1957 (USD 0.8 millions), third loan in 1958 (USD 6 millions), fourth loan in September 1959 (14 million) and, the last loan was in July 1960 with 33.8 millions (Hindley, 1963, pp. 108-109).

Romania also provided loan for Indonesia with the total amount of USD 52 million. The first loan was approved in March 1955 with USD 2 million and the second loan in November 1961 with USD 50 millions (Hindley, 1963, pp. 108-109). The other Eastern European states that provided loan for Indonesia were East Germany and Hungary. In February 1955 East Germany approved USD 9.2 millions to Indonesia. In September 1961 Hungary provided USD 29.6 millions loan for Indonesia (Hindley, 1963, pp. 108-109). The East European states provided the loans to Indonesia was strongly based on the cooperation and economic assistance of communist ideology and Soviet Union economic sphere of influence.

\section{Conclusion}

Indonesian relations with the Soviet Union, China Communists and East European states changed after 1965. The new Indonesian government under President Suharto banned the PKI. After the banning of the PKI and the rise of the "new order" regime, Indonesian relations with communist countries in Eastern Europe, Soviet Union and China Communists changed dramatically. This article concludes that the domestic political factor played greater role in Indonesian foreign relations. The changes of the domestic politics in Indonesia could not solely explain by merely discussing the developments at the domestic level. As structural realism argued that a state in the bipolarity structure is not free from the systemic level. The power configuration between two major powers influences the changes at the domestic level. The changes of domestic politics in Indonesia after Indonesian Coup of 30th September 1965 from "Old Order" under President Sukarno to "New Order" under President Suharto played greater role in influencing the Indonesian relations with Communists state, but the political development in domestic Indonesia was not free from the systemic level, i.e., the rivalries between The United States and the Soviet Union. No doubt that planning and strategies behind the Indonesian Coup of 30 September 1965 was the United States. The changes relations of Indonesia with the Soviet Union, China Communists and East European Communists states after 1965 are a part of international power configuration and rivalries between the United States and Soviet Union. 


\section{References}

Bert, W. (1975, June). Chinese Relations with Burma and Indonesia. Asian Survey, 25(6).

Derkach, N. (1965, November). The Soviet Policy towards Indonesia in the West Irian and the Malaysian Disputes. Asian Survey, 5(11), 566-571. http://dx.doi.org/10.2307/2642136

Feith, H. (1964, August). President Sukarno, The Army and The Communists: The Triangle Changes Shape. Asian Survey, 4(8), 969-980. http://dx.doi.org/10.2307/2642634

Hindley, D. (1963, Summer). Foreign Aid to Indonesia and Its Political Implications. Pacific Affairs, 36(2), 107-119. http://dx.doi.org/10.2307/2754184

Mahajani, U. (1967). Indonesia's New Order and the Diplomacy of Aid. The Australian Outlook, 21(2), 214-234. http://dx.doi.org/10.1080/10357716708444276

Nadesan, A. (1979, April-August). Sino-Indonesian Relations (1950-1967) and Its Future? Indian Journal of Politics, 20-27.

Reynolds, D. (2001). One World Divisible: A Global History since 1945. New York: W.W. Norton \& Company Inc.

Scott, P. D. (1985, Summer). The United States and Overthrow of Sukarno, 1965-1967. Pacific Affairs, 58(2), 239-264. http://dx.doi.org/10.2307/2758262

Singh, B. (1994). Indonesia-Soviet Relations. Jokjakarta: Gadjahmada University Press.

Steele, J. (1983). Soviet Power: The Kremlim's Foreign Policy-Brezhnez to Andropov. New York: Simon \& Schuster.

\section{Copyrights}

Copyright for this article is retained by the author(s), with first publication rights granted to the journal.

This is an open-access article distributed under the terms and conditions of the Creative Commons Attribution license (http://creativecommons.org/licenses/by/3.0/). 